\title{
L-Lactate Dehydrogenase A Chain
}

National Cancer Institute

\section{Source}

National Cancer Institute. L-Lactate Dehydrogenase A Chain. NCI Thesaurus. Code C106208.

L-lactate dehydrogenase A chain (332 aa, $\sim 37 \mathrm{kDa}$ ) is encoded by the human LDHA gene. This protein is involved in the metabolism of lactate and pyruvate. 